\title{
The influence of sand extraction on fish assemblages in campinarana streams in Cruzeiro do Sul - AC, Brazil
}

\author{
Ana Luiza Costa Silva * \\ Lucena Rocha Virgilio \\ Universidade Federal do Acre, Campus Floresta, Laboratório de Herpetologia \\ Estrada do Canela Fina, km 12, CEP 69.980-000, Cruzeiro do Sul - AC, Brasil \\ * Autor para correspondência \\ analuizacosta038@gmail.com
}

Submetido em 26/10/2018

Aceito para publicação em 13/05/2019

\section{Resumo}

Influência da extração de areia sobre a assembleia de peixes em riachos de Campinarana. A destruição de habitats, promovida pela extração de areia de leitos de riachos, pode causar a perda de algumas espécies e a alteração na dinâmica das assembleias de peixes. Assim, o presente estudo investigou o efeito da extração de areia sobre as assembleias de peixes em riachos de Campinarana, localizados na região de Cruzeiro do Sul, Acre, entre junho a agosto de 2017 e 2018. Seis riachos foram avaliados, sendo três degradados (pela extração de areia) e três florestados. Riqueza, diversidade de Shannon, equitabilidade e abundância de espécies foram avaliadas. Para verificar diferenças entre esses parâmetros, foi realizado o teste t de Student. NMDS e PERMANOVA foram sumarizadas para avaliar a composição de espécies de peixes. Foram coletadas 60 espécies de peixes com 705 indivíduos. Houve uma diferença significativa entre as áreas com relação à riqueza $(\mathrm{t}=11,1$; $\mathrm{p}=0,0001)$, à abundância $(\mathrm{t}=4,5 ; \mathrm{p}=0,006)$ e à diversidade $(\mathrm{t}=4,1 ; \mathrm{p}=0,01)$. A composição de espécies também variou (Pseudo- $F=3,79 ; p=0,01$ ), onde 35\% das espécies foram restritas aos ambientes preservados. Assim, sugere-se que a perturbação antrópica nas campinaranas, causou perda das espécies mais sensíveis e especializadas, permitindo o aumento dos indivíduos oportunistas, alterando a organização das assembleias e reduzindo a diversidade local.

Palavras-chave: Antropização; Composição de peixes; Diversidade; Ictiofauna; Vegetação ripária

\section{Abstract}

Habitat destruction promoted by sand extraction from streambeds can cause the loss of some species and change the dynamics of fish assemblages. The present study investigated the effect of sand extraction on fish assemblages in campinarana streams in the region of Cruzeiro do Sul, Acre, between June 2017 and August 2018. Six streams were evaluated, including three degraded by sand extraction and three in forested areas. Richness, a Shannon diversity index, equitability and abundance of species were evaluated. To verify differences between these parameters, a Student's t-test was conducted. NMDS and PERMANOVA were summarized to evaluate the composition of fish species. We collected 705 individuals distributed in 60 fish species. We found a significant difference between the areas regarding richness $(t=11.1, p=0.0001)$, abundance $(t=4.5, p=0.006)$ and diversity $(\mathrm{t}=4.1, \mathrm{p}=0.01)$. The species composition also varied (Pseudo- $\mathrm{F}=3.79, \mathrm{P}=0.01)$, since $35 \%$ of the species were restricted to preserved environments. Thus, it is suggested that the anthropic disturbance 
in the campinaranas caused the loss of the most sensitive and specialized species, which caused an increase in opportunistic individuals, altering the structure of the assemblages and reducing local diversity.

Key words: Anthropization; Diversity; Fish composition; Ichthyofauna; Riparian vegetation

\section{Introduction}

The Amazon basin has landscapes with white sand formations called campinaranas that cover approximately $7 \%$ of the region (DALY; PRANCE, 1989; SILVEIRA, 2003). Campina or campinarana vegetation is moderately extensive and ecologically peculiar, due to its adaptation to poor and acidic soil, different degrees of water availability, blackwater rivers and headwaters and varied habitat diversity, and constitutes one of the most fragile and vulnerable Amazonian ecosystems (DALY et al., 2016). This rare and restricted vegetation type covers only $66 \mathrm{~km}^{2}$ in southwestern Amazonia, or $0.04 \%$ of the state of Acre (ZEE-AC, 2006), and contains at least seven phytophysiognomies ranging from dense forest to formations, as described by Daly et al. (2016).

To a certain extent, the soil drainage of this campinarana vegetation complex restricts the practice of agriculture, and the absence of economic alternatives has resulted in the local population using and degrading natural resources, such a cutting and burning vegetation, the unsustainable extraction of forest resources, and especially the removal of vegetation cover to extract sand, which is a common practice in the region and other parts of Amazonia (FERREIRA et al., 2013). In this fragile environment, where there are undescribed (LÓPEZ-ROJAS et al., 2013), specialist and endemic species (GUILHERME; BORGES, 2011), sand mining associated with inadequate engineering has caused leaching, sedimentation, changes in species composition (RAMALHO et al., 2014) and the death of small streams.

These white sand environments have blackwater rivers and streams, regionally known as igarapés, which provide important ecosystem services (JANZEN, 1974). For example, streams filter and regulate the flow of terrestrial ecosystems, maintaining water quality, storing water flow during flooding and sustaining flow during drought (NAIMAN; DÉCAMPS, 1997). The dark color of these waters is due to the strong leaching of humic substances from organic matter decomposition in surrounding forests (JANZEN, 1974). These river systems are relatively fragile and depend on riparian vegetation to maintain their biotic integrity (HENRY, 2003).

Stream fish communities are structured based on geology, habitat size, temperature, streamflow velocity, substrate composition and interactions with other species (ALLAN, 2004; NEFF; JACKSON, 2012). Changes in these environments impact fish communities due to changes in environmental characteristics (e.g., water velocity and temperature) that influence species occurrence (WALSH et al., 2005), causing frequent species loss (STANFIELD; KILGOUR, 2013).

Biological communities can handle uncommon and low magnitude disturbances and may even maintain high species diversity during these changes (CONNELL, 1978). However, the continuity of a disturbance can eliminate more sensitive species, altering the communities' structure. Changes in habitat structure through deforestation in a watershed alter the trophic dynamics and may alter fish species diversity and composition (BOJSEN; BARRIGA, 2002; JOHNSON, 2002; CETRA; PETRERE Jr., 2006; FERREIRA; CASATTI, 2006).

Some studies, such as Karr (1981) and Magurran (2003), have determined the effect of changes in environmental characteristics in communities through assessment methods related to species richness and diversity. According to these authors, these methods allow the assessment and provide basic information on qualitative changes and emerging attributes (structure, composition and organization) of communities. Therefore, quantifying the effect of environmental modifications on aquatic communities is of great importance for understanding the structuring mechanisms of these communities and may provide inputs to predict the impact of anthropogenic influence on ecosystems (ANDERSON, 1981; SILVEIRA, 
2003). Thus, this can generate information that helps conservationist actions for systems that are disappearing at an overwhelming rate.

In this context, the present study aimed to evaluate the influence of sand removal on the fish community in a campinarana vegetation complex. Specifically, our goals were the following: (I) to determine if species richness, abundance, equitability, composition and diversity are influenced by anthropization due to sand removal; and (II) to assess which fish species are indicators of preserved and anthropized areas.

\section{Material and Methods}

\section{Study area}

The study was performed in a region of campinarana in the municipality of Cruzeiro do Sul, in northwestern Acre State, on the left margin of the Juruá River
(Table 1). Part of the vegetation is formed by species that tolerate periodic flooding and there is high amount of sclerophyllous vegetation (SILVEIRA, 2003) in the region (Figure 1).

TABLE 1: The geographic location of sampling points ST1 - Stream 1, ST2 - Stream 2, ST3 - Stream 3.

\begin{tabular}{cccc}
\hline $\begin{array}{c}\text { Degree of } \\
\text { preservation }\end{array}$ & Areas & Latitude (S) & Longitude (W) \\
\hline \multirow{4}{*}{ Preserved } & ST1 & $07^{\circ} 34^{\prime} 22.3^{\prime \prime}$ & $072^{\circ} 47^{\prime} 25.4^{\prime \prime}$ \\
& ST2 & $07^{\circ} 34^{\prime} 22.5^{\prime \prime}$ & $072^{\circ} 47^{\prime} 25.5^{\prime \prime}$ \\
& ST3 & $07^{\circ} 34^{\prime} 22.8^{\prime \prime}$ & $072^{\circ} 47^{\prime} 32.5^{\prime \prime}$ \\
\hline \multirow{4}{*}{ Anthropized } & ST1 & $07^{\circ} 34^{\prime} 22.3^{\prime \prime}$ & $072^{\circ} 47^{\prime} 19.2^{\prime \prime}$ \\
& ST2 & $07^{\circ} 34^{\prime} 21.5^{\prime \prime}$ & $072^{\circ} 47^{\prime} 27.3^{\prime \prime}$ \\
& ST3 & $07^{\circ} 34^{\prime} 23.1 ”$ & $072^{\circ} 47^{\prime} 32.5^{\prime \prime}$ \\
\hline
\end{tabular}

Six streams were evaluated within the campinarana area, in a region where there is extensive sand extraction (Figure 1). The stage of environmental degradation in

FIGURE 1: Location of the six sampled streams in a campinarana vegetation complex in the northwestern region of Acre, Brazil.

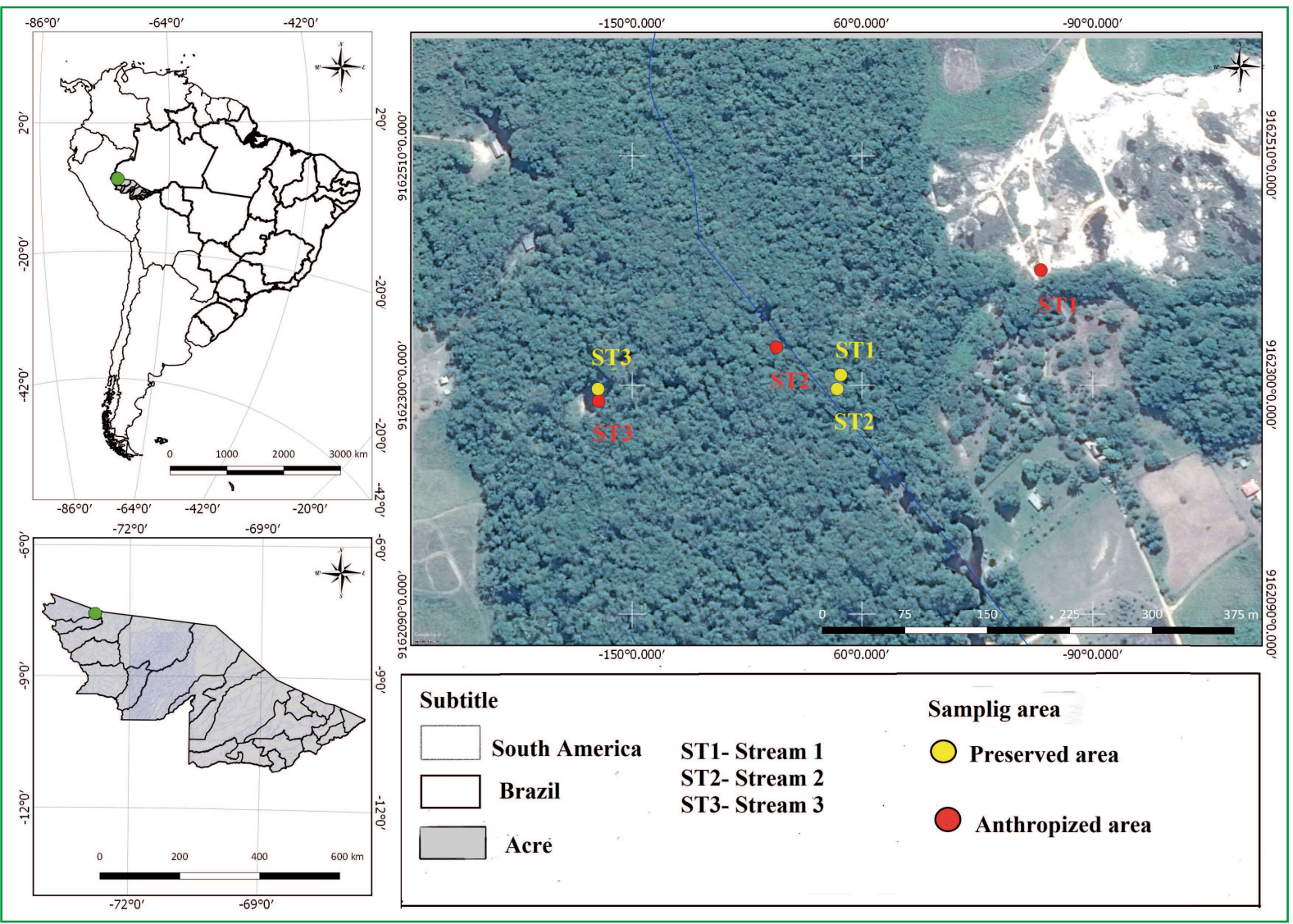


which the streambeds were found, due to unplanned exploration for mineral resources (sand), is clearly visible. During sampling, we observed the rapid advance of riparian forest loss, as a consequence of siltation, loss of remnant areas and highly inconstant soils.

\section{Sampling}

Sampling was carried out in six second-order streams (ICMBio license No. 11185-1 of 10/27/2007): (I) three with a high degree of riparian vegetation preservation; and (II) three with a high degree of degradation due to sand extraction. In each environment, $100 \mathrm{~m}$ plots were sampled. Sampling was performed during two dry periods, the first between June and August 2017 and the second between June and August 2018.

The ichthyofauna sampling was carried out using two collection methods: for backwater and low depth areas, two sieves $(80 \mathrm{~cm} \times 60 \mathrm{~cm})$ and one fishing net were used simultaneously for two hours in the morning and evening. In deeper places, three gill nets, $5 \mathrm{~m}$ long with $3 \mathrm{~cm}$ mesh, were installed. The nets were placed for four hours between the morning and evening. Sampling was performed in the opposite direction of water flow and included different biotopes, such as backwaters, source and marginal pools. The fish were anesthetized and fixed in $70 \%$ alcohol in a laboratory at the Federal University of Acre, and the species were identified to the lowest possible taxonomic level and confirmed by specialists. The taxonomic identification follows Reis et al. (2003) and Van der Laan et al. (2018). The specimens were later deposited in the fish collection of the Zoology Museum at the Universidade Estadual de Londrina (MZUEL), Londrina, Paraná, Brazil, and University Museum at the Universidade Federal do Acre (MUFAC), Rio Branco, Acre, Brazil (Attachment 1).

\section{Data analysis}

The description of fish community structure among streams was built from richness values, a ShannonWiener diversity index (H'), abundance and Pielou's equity $(\mathrm{J})$. To verify differences between these attributes between anthropized and forested areas, a Student's t-test was used.
To verify the sampling efficiency in community characterization and to compare species richness, rarefaction curves were used for interpolation based on the number of individuals in a standard sample. The $\mathrm{Z}$ test (ZAR, 1999) was used to test richness differences based on the rarefaction curves. Curves were generated using 999 permutations and the software EstimateS 9.1.0 (COLWELL, 2013).

Non-metric multidimensional scaling (NMDS) was applied to verify the fish community similarity between the collection points in the streams. NMDS was used for species abundance data, using the Bray-Curtis coefficient for similarity measures. A PERMANOVA (Permutational Multivariate Analysis of Variance) tested the multivariate differences in the Bray-Curtis matrix of fish species composition among the collection points in the streams. The PERMANOVA considered the samples from each stream as replicates. A Monte Carlo permutations test $(\mathrm{N}=999)$ of the similarity matrix was used to test the statistical significance of $P \leq 0.05$. NMDS and the PERMANOVA were performed using the software PRIMER version 6.0 (ANDERSON et al., 2008).

In order to verify which species were indicators of environmental condition among streams, an indicator value (IndVal) index was applied (DUFRÊNE; LEGENDRE, 1997), where the indicator value of a species ranges from 0 to 100 ; the maximum value is when all individuals of a species occur at all sites within a single group. The significance of the indicator value was tested for each species with a Monte Carlo test with 4999 permutations. For this analysis, the software PC-ORD version 5.0 (McCUNE; MEFFORD, 1999) was used.

\section{Results}

A total of 705 individuals distributed in five orders, 19 families and 60 species were found in the streams. The most representative orders were Characiformes and Siluriformes (33 species; 55\%, and $18 ; 30 \%$, respectively). The most abundant species of Characiformes were Hemigrammus sp. (250 individuals; $35.0 \%)$, Hyphessobrycon sp. (60; 8.4\%) and Carnegiella strigata $(30 ; 4.2 \%)$. The most representative species of 
Siluriformes were Helogenes marmoratus (28; 3.9\%), Tatia gyrina $(22 ; 3.08 \%)$ and Rineloricaria sp. (8; $1.12 \%$ ) (Table 2).

A total of 284 individuals were collected in streams with riparian vegetation, and the most abundant species in these areas were Hemigrammus sp. (39; 13.3\%),
Hypopygus lepturus (Hoedeman, 1962) (28; 9.7\%) and Gymnorhamphichthys rondoni $(22.7 \pm 3.2)$; these streams had the greatest richness $(22.7 \pm 3.2)$, diversity $(2.77 \pm 0.28)$ and equitability $(0.82 \pm 0.25)$ (Table 3$)$. For the anthropized streams, a total of 418 individuals were collected and the mean richness was $19.7 \pm 5.9$, the

TABLE 2: Fish fauna composition in three forested and three anthropized streams sampled in a campinarana vegetation complex in northwestern Acre, Brazil. ST1 - Stream 1; ST2 - Stream 2; ST3 - Stream 3.

\begin{tabular}{lllllllll}
\hline \multirow{2}{*}{ Order/Family/Species } & \multicolumn{3}{c}{ Forested } & \multicolumn{3}{c}{ Anthropized } \\
\cline { 2 - 7 } & ST1 & ST2 & ST3 & ST1 & ST2 & ST3 & Total \\
\hline
\end{tabular}

\section{Characiformes}

\section{Acestrorhynchidae}

Acestrorhynchus falcatus (Bloch, 1794)

Gnathocharax steindachneri (Fowler, 1913)

\begin{tabular}{lllllll}
2 & 1 & - & - & - & - & 3 \\
1 & - & - & 1 & - & - & 2 \\
\hline
\end{tabular}

\section{Characidae}

Aphyodite grammica (Eigenmann, 1912)

Hyphessobrycon cf. agulha (Fowler, 1913)

Hyphessobrycon cf. bentosi (Durbin, 1908)

Hyphessobrycon sp.

Hemigrammus sp.

Hemigrammus vorderwinkleri (Géry, 1963)

Hemigrammus ocellifer (Steindachner, 1882)

Hemigrammus cf. rodwayi (Durbin,_1909)

Hemigrammus cf. geisleri (Zarske \& Géry, 2007)

Hemigrammus melanochrous (Fowler, 1913)

Hemigrammus cf. coeruleus (Durbin, 1908)

Hemigrammus cf. neptunus (Zarske \& Géry, 2002)

Jupiaba anteroides (Géry, 1965)

Knodus sp.

Moenkhausia sp.

Moenkhausia mikia (Marinho \& Langeani, 2010)

Moenkhausia oligolepis (Günther, 1864)

Moenkhausia comma (Eigenmann, 1908)

Moenkhausia lepidura (Kner, 1858)

Paracheirodon sp.

Priocharax ariel (Weitzman \& Vari, 1987)

\section{Chilodontidae}

Chilodus punctatus (Müller \& Troschel, 1844)

Erythrinidae

Erythrinus erythrinus (Bloch \& Schneider, 1801)

Hoplias malabaricus (Bloch, 1794)

\section{Gasteropelecidae}

Carnegiella strigata (Günther, 1864)

\begin{tabular}{|c|c|c|c|c|c|c|}
\hline- & - & - & 1 & - & - & 1 \\
\hline - & - & - & 4 & - & - & 4 \\
\hline - & 1 & 1 & - & - & - & 2 \\
\hline 2 & 3 & 12 & 2 & - & 41 & 60 \\
\hline 17 & 17 & 5 & 116 & 7 & 88 & 250 \\
\hline- & - & 1 & - & - & - & 1 \\
\hline 9 & 2 & 1 & - & - & - & 12 \\
\hline- & 1 & - & - & - & - & 1 \\
\hline- & - & - & - & - & 1 & 1 \\
\hline- & - & - & 1 & - & - & 1 \\
\hline- & - & - & 22 & - & - & 22 \\
\hline- & - & - & 1 & - & - & 1 \\
\hline 4 & 3 & 1 & - & - & - & 8 \\
\hline- & - & - & 1 & - & 11 & 12 \\
\hline 7 & 3 & - & - & - & - & 10 \\
\hline 1 & - & 3 & - & 1 & - & 5 \\
\hline 1 & - & - & - & - & - & 1 \\
\hline 1 & 1 & - & - & 1 & - & 3 \\
\hline- & - & - & 2 & - & - & 2 \\
\hline 2 & - & - & 3 & - & - & 5 \\
\hline- & - & - & - & 4 & - & 4 \\
\hline- & - & - & 1 & - & - & 1 \\
\hline 1 & - & - & - & - & - & 1 \\
\hline- & 1 & - & - & - & - & 1 \\
\hline 12 & 5 & 3 & 4 & 5 & 1 & 30 \\
\hline
\end{tabular}




\section{Iguanodectidae}

Iguanodectes spilurus (Günther, 1864)

Bryconops sp.

Bryconops alburnoides (Kner, 1858)

Bryconops cf. caudomaculatus (Günther, 1864)

Lebiasinidae

Nannostomus cf. marginatus (Eigenmann, 1909)

Pyrrhulina cf. semifasciata (Steindachner, 1876)

\section{Cyprinodontiformes}

\section{Cynolebiidae}

Melanorivulus sp.

Gymnotiformes

Hypopomidae

Hypopygus lepturus (Hoedeman, 1962)

Rhamphichthyidae

Gymnorhamphichthys rondoni (Miranda Ribeiro, 1920)

$\begin{array}{ccccccc}12 & - & - & - & - & - & 12 \\ - & - & 1 & - & - & - & 1 \\ - & - & - & - & - & 13 & 13 \\ - & - & - & - & - & 3 & 3 \\ 3 & 9 & - & 4 & 1 & 4 & 21 \\ - & 5 & - & - & - & - & 5\end{array}$

\section{Sternopygidae}

Eigenmannia sp.

Sternopygus macrurus (Bloch \& Schneider, 1801)

\section{Siluriformes}

\section{Aspredinidae}

Bunocephalus coracoideus (Cope, 1874)

Auchenipteridae

Tatia gyrina (Eigenmann \& Allen, 1942)

Tatia dunni (Fowler, 1945)

Tetranematichthys quadrifilis (Kner, 1858)

Trachelyopterus galeatus ( Linnaeus, 1766)

Trachelyopterus taeniatus (Kner, 1857)

\section{Callichthyidae}

Corydoras seussi Dinkelmeyer, 1996

Megalechis picta (Müller \& Troschel, 1849)

\section{Cetopsidae}

Cetopsis plumbea Steindachner, 1882

Helogenes marmoratus Günther, 1863

\section{Loricariidae}

Ancistrus sp.

Hypoptopoma guianense Boeseman, 1974

Otocinclus macrospilus Eigenmann \& Allen, 1942

Rineloricaria sp.

\section{Heptapteridae}

Gladioglanis sp.

Myoglanis sp.

Pimelodella sp.

Rhamdia quelen (Quoy \& Gaimard, 1824)

$\begin{array}{lccccccc}- & - & 28 & - & 2 & 4 & 34 \\ 5 & 1 & 17 & 2 & 8 & 8 & 41 \\ - & - & - & - & - & 1 & 1 \\ - & - & - & - & - & 2 & 2\end{array}$

\begin{tabular}{lllllll}
- & 1 & 1 & - & 2 & 2 & 6 \\
1 & 10 & 2 & 5 & 2 & 2 & 22 \\
1 & - & - & - & - & - & 1 \\
- & - & - & 1 & - & - & 1 \\
- & - & - & 1 & - & - & 1 \\
& & & & & & \\
1 & 1 & - & - & - & - & 2 \\
- & - & 2 & 2 & - & - & 4 \\
& & & & & & \\
- & - & - & - & - & 1 & 1 \\
16 & - & 2 & 6 & - & 4 & 28 \\
& & & & & & \\
- & 4 & - & - & - & - & 4 \\
- & 1 & - & - & - & - & 1 \\
- & - & 2 & - & - & - & 2 \\
- & 2 & 1 & 3 & - & 2 & 8 \\
& & & & & & \\
- & 8 & - & - & - & - & 8 \\
- & - & - & - & - & 1 & 1 \\
- & - & - & 2 & - & - & 2 \\
3 & 1 & - & 2 & - & - & 6 \\
\hline & & & & & &
\end{tabular}




\section{Cichliformes}

Apistogramma cruzi Kullander, 1986

Bujurquina cf. robusta Kullander, 1986

Crenicichla semicincta Steindachner, 1892

Heros severus Heckel, 1840

mean diversity was $1.5 \pm 0.3$ and mean equitability was $0.5 \pm 0.2$ (Table 3 ). The dominant species were Hemigrammus sp. (211, 49.3\%) and Hyphessobrycon sp. $(43 ; 10.0 \%)$. Of the total number of collected species, $35 \%$ occurred in streams where sand had been extracted, which were all in the family Characidae $(N=9)$, and Hemigrammus cf. coeruleus $(\mathrm{N}=22)$ and Knodus sp. $(\mathrm{N}=12)$ were the most abundant. In the preserved areas, $35 \%$ of the species were also exclusive and Iguanodectes spilurus $(\mathrm{N}=12)$, Moenkhausia sp. $(\mathrm{N}=10)$ and Gladioglanis sp. $(\mathrm{N}=8)$ were the most abundant, which are in the families Iguanodectidae, Characidae and Heptapteridae, respectively (Table 2).

We found a significant difference between the anthropized and forested areas regarding species richness $(\mathrm{t}=11.1 ; \mathrm{p}=0.0001)$, abundance $(\mathrm{t}=4.5, \mathrm{p}=0.006)$ and diversity $(\mathrm{t}=4.1, \mathrm{p}=0.01)($ Table 3$)$.

Variations in the attributes of assemblages are also shown in rarefaction curves, where accumulated richness of stretches within forest environments are greater compared to anthropized environments $(Z=-2.29$, $\mathrm{p}=0.02)($ Figure 2).

After four interactions, the stability criterion of NMDS was reached with a final stress value of 0.12 . The first two axes explained $54 \%$ of the variation in fish composition between the stretches, with the first axis capturing $30 \%$ of the variance and the second $24 \%$. Ordination separated the groups formed by the stretches based on fish species composition (Figure 3). There was a significant difference between streams regarding fish species composition (Pseudo- $F=3.79 ; \mathrm{p}=0.01$ ). The post-hoc comparisons of the interactions showed differences between preserved and degraded streams $(\mathrm{P}=0.012)$.

The indicator species that had more influence on stream ordination were Acestrorhynchus falcatus ( $\mathrm{p}=$ $0.01)$ and Carnegiella strigata $(\mathrm{p}=0.01)$, and the greatest mean abundance was in forested streams. Hemigrammus cf. coeruleus $(\mathrm{p}=0.02)$ and Hemigrammus sp. $(\mathrm{p}=$ 0.02 ) had the greatest mean abundance in anthropized streams (Table 4).

TABLE 3: Comparison between mean values of species richness, abundance, equitability and diversity generated by the Shannon index for forested and anthropized streams sampled in a campinarana vegetation complex in northwestern Acre, Brazil. ST1 - Stream 1; ST2 - Stream 2; ST3 - Stream 3.

\begin{tabular}{cccccc}
\hline Areas & Sites & Richness (S) & Abundance (n) & Diversity (H') & Equitability (J) \\
\hline \multirow{4}{*}{ Forested } & ST1 & 24 & 112 & 2.70 & 0.85 \\
& ST2 & 23 & 82 & 2.68 & 0.85 \\
& ST3 & 20 & 91 & 2.25 & 0.77 \\
\hline \multirow{3}{*}{ Anthropized } & ST1 & 24 & 191 & 1.69 & 0.54 \\
& ST2 & 12 & 35 & 2.18 & 0.88 \\
& ST3 & 21 & 193 & 1.90 & 0.62 \\
\hline $\mathbf{t}$ & & 11.1 & 4.5 & 4.1 & 13.1 \\
\hline $\mathbf{p}$ & & 0.0001 & 0.006 & 0.01 & 4.45 \\
\hline
\end{tabular}


FIGURE 2: Rarefaction curves based on fish specimen number sampled in low-order streams in a campinarana area, in northwestern Acre, Brazil.

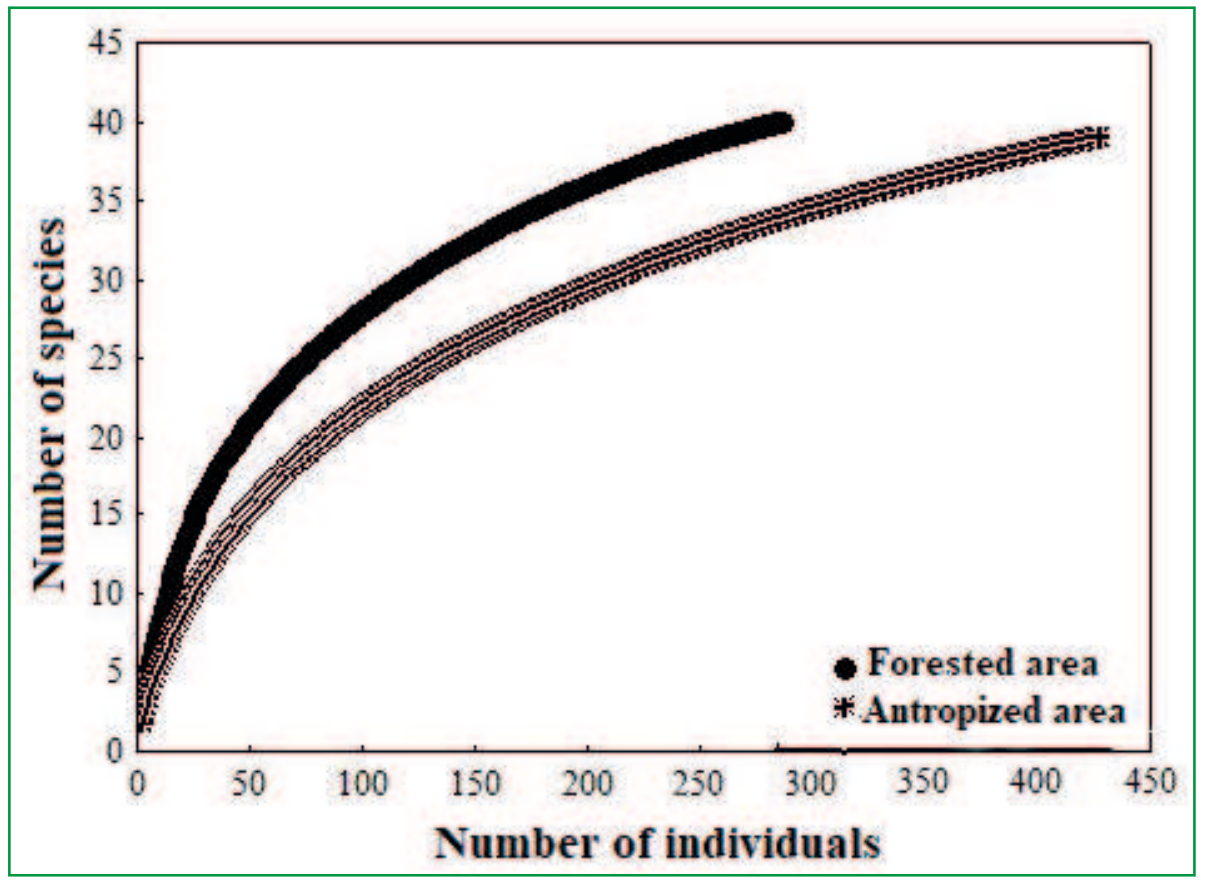

FIGURE 3: Non-metric multidimensional scaling of the fish community of stretches of forested and anthropized streams sampled in a campinarana vegetation complex in northwestern Acre, Brazil.

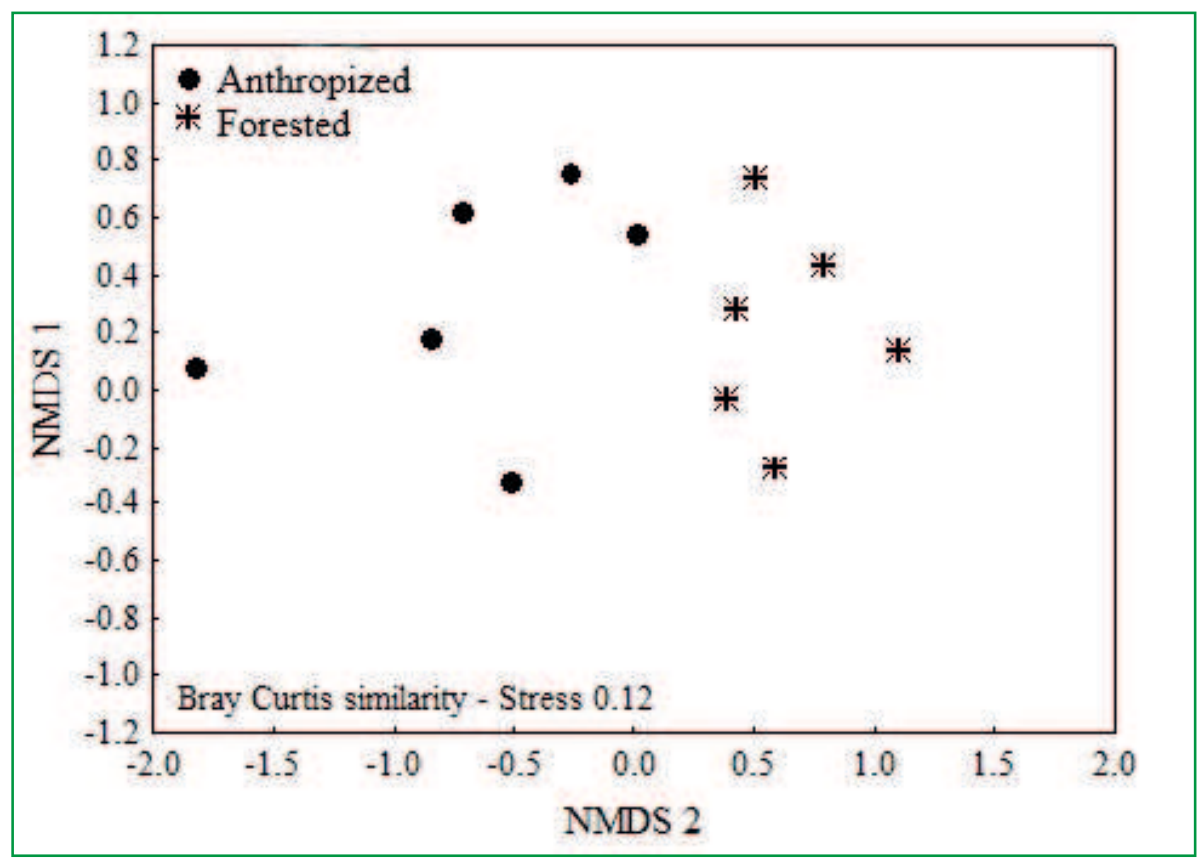


TABLE 4: Indicator value (IndVal) of sampled species of stretches of forested and anthropized streams in a campinarana vegetation complex in northwestern Acre, Brazil.

\begin{tabular}{llcccc}
\hline Species & Site & INDVAL & Mean & Stand. Dev. & p \\
\hline Acestrorhynchus falcatus & Forested & 71.8 & 25.3 & 8.79 & 0.01 \\
Carnegiella strigata & Forested & 60 & 18.4 & 8.59 & 0.01 \\
Jupiaba anteroides & Forested & 51.5 & 39.3 & 6.27 & 0.04 \\
Hemigrammus ocellifer & Forested & 50 & 28.2 & 12.2 & 0.01 \\
Hemigrammus sp. & Anthropized & 73 & 24.4 & 10.06 & 0.02 \\
Knodus sp. & Anthropized & 64.8 & 36.2 & 7.86 & 0.02 \\
Hemigrammus cf. coeruleus & Anthropized & 65.3 & 24.1 & 10.06 & 0.02 \\
\hline
\end{tabular}

\section{Discussion}

The present study revealed that the removal of sand in small areas of streams diminished the richness and diversity of fish and increased the abundance of some species. The fish fauna composition also varied between anthropized and forested areas, in which the species composition was influenced by the degradation of the stream areas. These data are similar to those of other studies about aquatic communities exposed to habitat degradation gradients (KIKUCHI; UIEDA, 1998; JOHNSON; HERING, 2009). Thus, we can suggest that for any frequent disturbance, there is a logical tendency towards a reduction in species richness and diversity due to the modified environment, which eliminates more sensitive and specialized species and allows opportunistic and adapted species to become dominant, altering the organization of assemblages and reducing local diversity, as evidenced in studies by Margalef (1963), Casatti (2004) and Felipe and Súarez (2010). Mining and deforestation can reduce canopy cover and, therefore, increase water brightness and temperature, as well as reduce the input of organic matter (WRIGHT; FLECKER, 2004). Specimens of small size, such as Hemigrammus sp. and Hyphessobrycon sp., were more numerous in these degraded areas. In addition, the majority of the indicator species of the anthropized areas were also small characids, for example, Hemigrammus cf. coeruleus and Knodus sp. As pointed out by Rezende and Mazzoni (2003), many characids are opportunistic in relation to the use of resources in stream environments. This may have influenced the high dominance of these species, which benefit from the new opportunities created by habitat degradation (GORMAN; KARR, 1978; HORN, 1998; CASTRO, 1999).

In addition to Hemigrammus sp., the species with the highest number of individuals in the preserved areas belong to the order Gymnotiformes (G. rondoni and $H$. lepturus). It is probable that the decrease of individuals of these species in anthropized areas is related to the modified substrate, since in these environments the transport of marginal sediments and the removal of substrates cause the bottoms of the streams to become clayey with little organic matter (BLEICH et al., 2014). The substrate is a complex aspect of the physical environment (ALLAN; CASTILLO, 2007) and can act as refuge for fish fauna. For these two species, this microhabitat functions as a hiding place against predators, a safe place to rest during the day, and for feeding and foraging during the night (ZUANON et al., 2006).

The present study found evidence that Acestrorhynchus falcatus is an indicator species of the preserved environments. Acestrorhynchus species live in freshwater systems throughout South America, east of the Andes, and most of the species occur in the Amazon and basins of the Orinoco River and rivers in the Guianas (11 species); two species are restricted to the São Francisco River and basins of the upper Paraná River, in Brazil, and one species is in the basins of the lower Paraná River, in Paraguay and Uruguay (MENEZES, $1969 ;$ 1992). Small species are found in small streams (PRETTI et al., 2009; FROESE; PAULY, 2018) and have been observed in preserved environments by Brosse et al. (2011) and Virgilio et al. (2018). Although Carnegiella 
strigata was found in anthropized environments in the present study, we also found it as an indicator of the preserved areas due to the great abundance of individuals in these streams. According to Silva (1993), this species is strongly associated with surrounding vegetation, mostly occurs in places with roots and branches close to the banks, and mainly eats insects. This may have influenced the strong association with surrounding vegetation.

The present study also indicated that $35 \%$ of the collected species were restricted to the preserved environments, revealing a modification in the species composition between the degraded and preserved areas. However, according to Iwata et al. (2003) and Deegan et al. (2011), it is expected that changes in the structural patterns of a biological community are common due to impacts caused by different land uses. In this context, the unsustainable extraction of sand for civil construction caused the exclusion and substitution of fish species in the campinarana areas.

In relation to the adjacent mainland forests of the Amazon, it is expected that species richness in the campinarana environments is smaller, but studies indicate that these areas are rich in endemic species and may contain undescribed species (LÓPEZ-ROJAS et al., 2013; GUILHERME; BORGES, 2011). In the present study, species of several genera still need to be identified (sp.) and compared (cf.), and the degradation of these habitats may lead to the local extinction of these taxa. Sand mining is regulated by Federal Law No. 8,982, from 1995, and states "it may be used by the licensing regime, or authorization and concession, as follows: I - sands, gravel and pea gravel for immediate use under construction." The illegal extraction of sand in Brazil is a crime (Article 2 of Law No. 8,166, from 1991, and Article 55 of Law No. 9,605, from 1998) and there are penalties and fines for those who extract mineral resources without authorization or a license. However, there is a lack of effective control by environmental agencies, which end up "allowing" the free extraction of sand without the apparent requirement of an environmental impact and recovery study about the area. In this sense, the present study is a practical example of the consequences of non-sustainable exploration of a natural resource by a local population stimulated by large corporations. The local communities benefit from this at first, but the corporations do not invest in relevant and lasting socioeconomic constructs. On the contrary, they monopolize exploration and profits by implementing an unsustainable and immediate exploration policy, increase the use of natural resources, are private, and abandon the areas. Therefore, regeneration and conservation actions related to these areas of campinarana are of utmost importance due to the high degree of endemism and great possibility of new species. This includes planning and monitoring usage, which will ensure strategic measures for maintaining plant and animal populations in these patches of vegetation on white sand. Socio-educational measures, management and sustainability actions are necessary to combat livestock breeding, illegal land invasion and questionable financial transactions related to land use, such as the extraction of sand and mud.

\section{Acknowledgments}

We thank CNPq (Conselho Nacional de Desenvolvimento Científico e Tecnológico) for the financial support, the Herpetology Laboratory at the Federal University of Acre, and the Professors Dr. Oscar Akio Shibatta, Dr. José Birindelli and Dr. Fernando Jerep from the State University of Londrina - UEL.

\section{Attachment 1}

List of specimens deposited in the collection of the Zoology Museum of the State University of Londrina (MZUEL) and University Museum of the Federal University of Acre (MUFAC).

Acestrorhynchus falcatus: MZUEL 17822. Gnathocharax steindachneri: MZUEL 17902. Aphyodite grammica: MZUEL 17816. Hyphessobrycon cf. agulha: MZUEL 17817. Hyphessobrycon cf. bentosi: MZUEL 17911. Hyphessobrycon sp.: MZUEL 17908. Hemigrammus sp.: MZUEL 17837. Hemigrammus vorderwinkleri: MZUEL 17928. Hemigrammus ocellifer: MZUEL 17840. Hemigrammus cf. rodwayi: MZUEL 17839. Hemigrammus cf. geisleri: MZUEL 17907. 
Hemigrammus melanochrous: MZUEL 17912. Hemigrammus cf. coeruleus: MZUEL 17917. Hemigrammus cf. neptunus: MZUEL 17927. Jupiaba anteroides: MZUEL 17895. Knodus sp.: MZUEL 17820. Moenkhausia sp.: MZUEL 17870. Moenkhausia mikia: MZUEL 17824. Moenkhausia oligolepis: MZUEL 17818. Moenkhausia comma: MZUEL 17828. Moenkhausia lepidura: MZUEL 17909. Paracheirodon sp.: MZUEL 17910. Priocharax ariel: MZUEL 17914. Chilodus punctatus: MZUEL 17877. Erythrinus erythrinus: MZUEL 17815. Hoplias malabaricus: MZUEL 17871. Carnegiella strigata: MUFAC 778. Iguanodectes spilurus: MZUEL 17896. Bryconops sp.: MZUEL 17821. Bryconops alburnoides: MZUEL 17899. Bryconops cf. caudomaculatus: MZUEL 17906. Nannostomus cf. marginatus: MZUEL 17866. Pyrrhulina cf. semifasciata: MZUEL 17872. Melanorivulus sp.: MZUEL 17903. Hypopygus lepturus: MZUEL 17826. Gymnorhamphichthys rondoni: MUFAC 779. Eigenmannia sp.: MZUEL 17879. Sternopygus macrurus: MZUEL 17891. Bunocephalus coracoideus: MZUEL 17882. Tatia gyrina: MZUEL 17885. Tatia dunni: MZUEL 17894. Tetranematichthys quadrifilis: MZUEL 17823. Trachelyopterus galeatus: MZUEL 17893. Trachelyopterus taeniatus: MZUEL 17883. Corydoras seussi: MZUEL 17814. Megalechis picta: MZUEL 17913. Cetopsis plumbea: MZUEL 17886. Helogenes marmoratus: MUFAC 780. Ancistrus sp.: MZUEL 17890. Hypoptopoma guianense: MZUEL 17867. Otocinclus macrospilus: MZUEL 17887. Rineloricaria sp.: MZUEL 17865. Gladioglanis sp.: MZUEL 17868. Myoglanis sp.: MZUEL 17897. Pimelodella sp.: MZUEL 17875. Rhamdia quelen: MZUEL 17881. Apistogramma cruzi: MZUEL 17825. Bujurquina cf. robusta: MZUEL 17892. Crenicichla semicincta: MZUEL 17878. Heros severus: MZUEL 17876.

\section{References}

ALLAN, J. D. Landscapes and riverscapes: the influence of land use on stream ecosystems. Annual Review of Ecology, Evolution, and Systematics, Palo Alto, v. 35, p. 257-284, 2004.
ALLAN, J. D.; CASTILLO, M. M. Stream ecology: structure and function of running waters. Berlin: Springer Science \& Business Media, 2007. $436 \mathrm{p}$.

ANDERSON, A. B. White-sand vegetation of Brazilian Amazonia. Biotropica, Malden, v. 13, p. 199-210, 1981.

ANDERSON, M. J.; GORLEY, R. N.; ClARKE, K. R. PERMANOVA + for PRIMER: guide to software and statistical methods. Plymouth: PRIMES-E, 2008. 214 p.

BLEICH, M. E.; MORTATI, A. F.; ANDRÉ, T.; PIEDADE, M. T. F. Riparian deforestation affects the structural dynamics of headwater streams in Southern Brazilian Amazonia. Tropical Conservation Science, Menlo Park, v. 7, n. 4, p. 657-676, 2014.

BOJSEN, B. H.; BARRIGA, R. Effects of deforestation on fish community structure in Ecuadorian Amazon streams. Freshwater Biology, London, v. 47, n. 11, p. 2246-2260, 2002.

BROSSE, S.; GRENOUILLET, G.; GEVREY, M.; KHAZRAINE, K.; TUDESQUE, L. Small-scale gold mining erodes fish assemblage structure in small neotropical streams. Biodiversity and Conservation, New York, v. 20, n. 5, p. 1013-1026, 2011.

CASATTI, L. Ichthyofauna of two streams (silted and reference) in the upper Paraná river basin, Southeastern Brazil. Brazilian Journal of Biology, São Carlos, v. 64, n. 4, p. 757-765, 2004.

CASTRO, R. M. C. Evolução da ictiofauna de riachos sulamericanos: padrões gerais e possíveis processos causais. In: CARAMASCHI, E. P., MAZZONI, R.; PERES-NETO, P. R. (Ed.). Ecologia de peixes de riachos. Série Oecologia Brasiliensis. Rio de Janeiro: Computer - Publish Editoração Ltda, 1999. p. 139-155. CETRA, M.; PETRERE Jr., M. Fish assemblage structure of the Corumbataí River Basin, São Paulo State, Brazil: Characterization and anthropogenic disturbances. Brazilian Journal of Biology, São Carlos, v. 66, n. 2A, p. 431-439, 2006.

CONNELL, J. H. Diversity in tropical rain forests and coral reefs. Science, New York, v. 199, n. 4335, p. 1302-1310, 1978.

COLWELL, R. K. EstimateS 9.1. 0 user's guide. Connecticut: University of Connecticut, 2013.

DALY, D. C.; PRANCE, G. T. Brazilian Amazon. In: CAMPBELL D. G.; HAMMOND, H. D. (Ed.). Floristic inventory of tropical countries: the status of plant systematics, collections, and vegetation, plus recommendations for the future. New York: New York Botanical Garden, 1989. p. 401-426.

DALY, D. C.; SILVEIRA, M.; MEDEIROS, H.; CASTRO, W.; OBERMÜLLER, F. A. The White-sand Vegetation of Acre, Brazil. Biotropica, Malden, v. 48, n. 1, p. 81-89, 2016.

DEEGAN, L. A.; NEILL, C.; HAUPERT, C. L.; BALLESTER, M. V. R.; KRUSCHE, A. V.; VICTORIA, R. L.; MOOR, E. Amazon deforestation alters small stream structure, nitrogen biogeochemistry and connectivity to larger rivers. Biogeochemistry, Dordrecht, v. 105, n. 1-3, p. 53-74, 2011.

DUFRÊNE, M.; LEGENDRE, P. Species assemblages and indicator species: the need for flexible asymmetrical approach. Ecological Monographs, Ithaca, v. 67, n. 3, p. 345-366, 1997.

FELIPE, T. R. A.; SÚAREZ, Y. R. Characterization and influence of environmental factors on stream fish assemblages in two small urban sub-basins, Upper Paraná River. Biota Neotropica, Campinas, v. 10, n. 2, p. 143-151, 2010. 
FERREIRA, C. P.; CASATTI, L. Integridade biótica de um córrego na bacia do Alto Rio Paraná avaliada por meio da comunidade de peixes. Biota Neotropica, Campinas, v. 6, n. 3, p. 1-25, 2006.

FERREIRA, L.; CHAVES, P. P.; CUNHA, D. D. A.; ROSÁRIO, A. S.; PAROLIN, P. A extração ilegal de areia como causa do desaparecimento de Campinas e Campinaranas no Estado do Pará, Brasil. Pesquisas, Botânica, São Leopoldo, v. 64, p. 157-173, 2013.

FROESE, R.; PAULY, D. FishBase (version10/2018). 2018. Available in: $<$ www.fishbase.org $>$.

GORMAN, O. T.; KARR, J. R. Habitat structure and stream fish communities. Ecology, New York, v. 59, n. 3, p. 507-515, 1978.

GUILHERME, E.; BORGES, S. Ornithological records from a Campina/Campinarana enclave on the Upper Juruá River, Acre, Brazil. The Wilson Ornithological Society, Ann Arbor, v. 123, p. 24-32, 2011.

IWATA, T.; NAKANO, S.; INOUE, M. Impacts of past riparian deforestation on stream communities in a tropical rain forest in Borneo. Ecological Applications, Ithaca, v. 13, n. 2, p. 461-473, 2003.

HENRY, R. Os ecótonos nas interfaces dos ecossistemas aquáticos: conceitos, tipos, processos e importância. Estudo de aplicação em lagoas marginais ao rio Paranapanema na zona de sua desembocadura na Represa de Jurumirim. In: HENRY, R. (Ed.). Ecótonos nas interfaces dos ecossistemas aquáticos. São Carlos: Rima, 2003. p. 1-28.

HORN, M. H. Feeding and digeston. In: EVANS, D. H. (Ed.). The physiology of fishes. Boca Roton: CRC Press, 1998. p. 43-64.

JANZEN, D. H. Tropical blackwater rivers, animals, and mast fruiting by the Dipterocarpaceae. Biotropica, Malden, v. 6,1 p. 69103,1974 .

JOHNSON, R. K.; HERING, D. Response of taxonomic groups in streams to gradients in resource and habitat characteristics. Journal of Applied Ecology, London, v. 46, p. 175-186, 2009.

JOHNSON, W. C. Riparian vegetation diversity along regulated rivers: contribution of novel and relict habitats. Freshwater Biology, London, v. 47, p. 749-759, 2002.

LÓPEZ-ROJAS, J. J.; RAMALHO, W. P.; SILVEIRASUSÇUARANA, M.; SOUZA, M. B. Three new records of Pristimantis (Amphibia: Anura: Craugastoridae) for Brazil and a comment of the advertisement call of Pristimantis orcus. Check List, Rio Claro, v. 9, n. 6, p. 1548-1551, 2013.

KARR, J. R. Assessment of biotic integrity using fish communities. Fisheries, Bethesda, v. 6, n. 6, p. 21-27, 1981.

KIKUCHI, R. M.; UIEDA, V. S. Composição da comunidade de invertebrados de um ambiente lótico tropical e sua variação espacial e temporal. In: NESSIMIAN, J. L.; CARVALHO, A. L. (Ed.). Ecologia de insetos aquáticos. Série Oecologia Brasiliensis. Vol. 5. Rio de Janeiro: PPGE-UFRJ, 1998. p. 157-173.

MAGURRAN, A. E. Measuring biological diversity. Malden: Blackwell Publishing, 2003. 264 p.

MARGALEF, R. On certain unifying principles in ecology. The American Naturalist, Chicago, v. 97, n. 897, p. 357-374, 1963.

MENEZES, N. A. Systematics and evolution of the tribe Acestrorhynchini (Pisces, Characidae). Arquivos de Zoologia, São Paulo, v. 18, n. 1-2, p. 1-150, 1969.
MENEZES, N.A. Redefinição taxonômica das espécies de Acestrorhynchus do grupo lacustris com a descrição de uma nova espécie (Osteichthyes, Characiformes, Characidae). Comunicações do Museu de Ciência e Tecnologia da PUCRS, Porto Alegre, v. 5, p. 39-54, 1992.

McCUNE, B.; MEFFORD, M. J. PC-ORD. Multivariate Analysis of Ecological Data. Version 5.0. Gleneden Beach: MjM Software, 1999.

NAIMAN, R.J.; DÉCAMPS, H. The ecology of the interfaces; riparian zones. Annual Review of Ecology and Systematics, Palo Alto, v. 28, p. 621-658, 1997.

NEFF, M. R.; JACKSON, D. A. Geology as a structuring mechanism of stream fish communities. Transactions of the American Fisheries Society, Oxford, v. 141, n. 4, p. 962-974, 2012.

PRETTI, V. Q.; CALCAGNOTTO, D.; TOLEDO-PIZA, M.; de ALMEIDA-TOLEDO, L. F. Phylogeny of the Neotropical genus Acestrorhynchus (Ostariophysi: Characiformes) based on nuclear and mitochondrial gene sequences and morphology: a total evidence approach. Molecular Phylogenetics and Evolution, Oxford, v. 52, n. 2, p. 312-320, 2009.

RAMALHO, W. P.; DA SILVEIRA SUSÇUARANA, M.; LÓPEZROJAS, J. J.; ROCHA, L. V.; KEPPELER, E. C.; SOARES VIEIRA, L. J. Impacto do assoreamento sobre a diversidade de peixes em igarapés de um complexo vegetacional de Campinarana no noroeste do Acre, Brasil. Neotropical Biology \& Conservation, São Leopoldo, v. 9, n. 2, p. 105-114, 2014.

REIS, R. E.; KULLANDER, S. O.; FERRARIS, C. J. Introduction. In: REIS, R. E.; KULLANDER, S. O.; FERRARIS, C. J. (Ed.). Checklist of the freshwater fishes of South and Central America. Porto Alegre: Edipucrs, 2003. p. 1-9.

REZENDE, C. F.; MAZZONNI, R. Aspectos da alimentação de Bryconamericus microcephalus (Characiformes, Tetragonopterinae) no Córrego Andorinha. Biota Neotroprica, Campinas, v. 3, n. 1, p. 1-6, 2003.

SILVA, C. P. Alimentação e distribuição espacial de algumas espécies de peixes do igarapé do Candirú, Amazonas, Brasil. Acta Amazonica, Manaus, v. 23, n. 2, p. 271-285, 1993.

SILVEIRA, M. Vegetação e flora das Campinaranas do Sudoeste Amazônico (JU-008). Relatório de Defesa Técnica. Rio Branco: Associação S.O.S. Amazônia, 2003. 28 p.

STANFIELD, L. W.; KILGOUR, B. W. How proximity of land use affects stream fish and habitat. River Research and Applications, Chichester, v. 29, n. 7, p. 891-905, 2013.

VAN DER LAAN, R.; FRICKE, R.; ESCHMEYER, W. N. Catalog of fishes: classification (Electronic version). 2018. Available in: $\quad<$ http://www.calacademy.org/scientists/catalog-of-fishes classification $/>$.

VIRGILIO, L. R.; RAMALHO, W. P.; SILVA, J. C. B. Does riparian vegetation affect fish assemblage? A longitudinal gradient analysis in three Amazonian streams. Acta Scientiarum. Biological Sciences, Maringá, v. 40, e42562, 2018.

WALSH, C. J.; ROY, A. H.; FEMINELLA, J. W.; COTTINGHAM, P. D.; GROFFMAN, P. M.; MORGAN, R. P. The urban stream syndrome: current knowledge and the search for a cure. Journal of the North American Benthological Society, Lawrence, v. 24, n. 3 , p. 706-723, 2005. 
WRIGHT, J. P.; FLECKER, A. S. Deforesting the riverscape: the effects of wood on fish diversity in a Venezuelan piedmont stream. Biological Conservation, Boston, v. 120, n. 3, p. 439-447, 2004.

ZAR, J. H. Biostatistical analysis. New Jersey, Prentice Hall, 1999. $663 \mathrm{p}$.

ZEE-AC. Zoneamento ecológico-econômico do Acre - Fase II. Rio Branco: Secretaria Estadual de Meio Ambiente (SEMA, 2010. Available from <https://docplayer.com.br/7642615-Zoneamentoecologico-economico-do-acre-fase-ii.html $>$.
ZUANON, J.; BOCKMANN, F. A.; SAZIMA, I. A remarkable sand-dwelling fish assemblage from central Amazonia, with comments on the evolution of psammophily in South American freshwater fishes. Neotropical Ichthyology, Maringá, v. 4, n. 1, p. 107-118, 2006. 